\title{
Multivesicular exocytosis in rat pancreatic beta cells
}

\author{
M. B. Hoppa • E. Jones • J. Karanauskaite • \\ R. Ramracheya - M. Braun - S. C. Collins - Q. Zhang • \\ A. Clark • L. Eliasson • C. Genoud • P. E. MacDonald • \\ A. G. Monteith - S. Barg • J. Galvanovskis • P. Rorsman
}

Received: 13 June 2011 / Accepted: 17 November 2011 / Published online: 22 December 2011

(C) The Author(s) 2011. This article is published with open access at Springerlink.com

\begin{abstract}
Aims/hypothesis To establish the occurrence, modulation and functional significance of compound exocytosis in insulin-secreting beta cells.

Methods Exocytosis was monitored in rat beta cells by electrophysiological, biochemical and optical methods. The functional assays were complemented by three-dimensional reconstruction of confocal imaging, transmission and block face scanning electron microscopy to obtain ultrastructural evidence of compound exocytosis.
\end{abstract}

Electronic supplementary material The online version of this article (doi:10.1007/s00125-011-2400-5) contains peer-reviewed but unedited supplementary material, which is available to authorised users.

M. B. Hoppa $\cdot$ E. Jones $\cdot$ J. Karanauskaite $\cdot$ R. Ramracheya $\cdot$

M. Braun - S. C. Collins - Q. Zhang - A. Clark ·J. Galvanovskis •

P. Rorsman $(\bowtie)$

Oxford Centre for Diabetes, Endocrinology and Metabolism,

University of Oxford,

Oxford OX3 7LJ, UK

e-mail: patrik.rorsman@drl.ox.ac.uk

L. Eliasson

Lund University Diabetes Centre, Clinical Research Centre,

Malmo, Sweden

C. Genoud

Friedrich Miescher Institute for Biomedical Research,

Basel, Switzerland

P. E. MacDonald

Department of Pharmacology, University of Alberta,

Edmonton, Canada

\author{
A. G. Monteith \\ Gatan UK, \\ Abingdon, UK \\ S. Barg \\ Department of Medical Cell Biology, Uppsala University, \\ Uppsala, Sweden
}

Results Compound exocytosis contributed marginally $(<5 \%$ of events) to exocytosis elicited by glucose/membrane depolarisation alone. However, in beta cells stimulated by a combination of glucose and the muscarinic agonist carbachol, $15-20 \%$ of the release events were due to multivesicular exocytosis, but the frequency of exocytosis was not affected. The optical measurements suggest that carbachol should stimulate insulin secretion by $\sim 40 \%$, similar to the observed enhancement of glucose-induced insulin secretion. The effects of carbachol were mimicked by elevating $\left[\mathrm{Ca}^{2+}\right]_{\mathrm{i}}$ from 0.2 to $2 \mu \mathrm{mol} / 1 \mathrm{Ca}^{2+}$. Two-photon sulforhodamine imaging revealed exocytotic events about fivefold larger than single vesicles and that these structures, once formed, could persist for tens of seconds. Cells exposed to carbachol for $30 \mathrm{~s}$ contained long $(1-2 \mu \mathrm{m})$ serpentine-like membrane structures adjacent to the plasma membrane. Three-dimensional electron microscopy confirmed the existence of fused multigranular aggregates within the beta cell, the frequency of which increased about fourfold in response to stimulation with carbachol.

Conclusions/interpretation Although contributing marginally to glucose-induced insulin secretion, compound exocytosis becomes quantitatively significant under conditions associated with global elevation of cytoplasmic calcium. These findings suggest that compound exocytosis is a major contributor to the augmentation of glucose-induced insulin secretion by muscarinic receptor activation.

Keywords Beta cell $\cdot \mathrm{Ca}^{2+} \cdot$ Exocytosis
Abbreviations
CAMKII $\mathrm{Ca}^{2+} /$ calmodulin-dependent protein kinase 2
$\left[\mathrm{Ca}^{2+}\right]_{\mathrm{i}} \quad$ Cytoplasmic free calcium concentration
$\Delta C_{\mathrm{m}} \quad$ Change in membrane capacitance
HW Half width (time during which current exceeds $50 \%$ of the peak value) 


$\begin{array}{ll}\text { PKC } & \text { Protein kinase C } \\ \mathrm{P} 2 \mathrm{X}_{2} \mathrm{R} & \text { P2X purinoreceptor } 2 \\ Q & \text { Charge (integrated current) } \\ \mathrm{SRB} & \text { Sulforhodamine } \\ 3-\mathrm{D} & \text { Three-dimensional } \\ t_{10-90 \%} & \text { Rise time (time it takes for current to increase } \\ & \text { from } 10 \% \text { to } 90 \% \text { of peak value) }\end{array}$

\section{Introduction}

Insulin is secreted from the pancreatic beta cells by $\mathrm{Ca}^{2+}$ dependent exocytosis [1]. Release of insulin is thought to involve the fusion of individual granules with the plasma membrane [2, 3]. High-resolution capacitance measurements have confirmed that most exocytotic events occur as the fusion of individual secretory granules [4]. However, about $10 \%$ of the exocytotic events were associated with larger stepwise increases in membrane capacitance [4] as if multiple granules fused simultaneously with the plasma membrane (compound exocytosis).

There are two types of compound exocytosis [5]. Sequential exocytosis starts with a primary fusion event at the plasma membrane, and other granules subsequently fuse with this granule. In multivesicular release, several granules first fuse within the cell before undergoing exocytosis as one unit. Sequential exocytosis has been reported in a variety of cells [6-9], including pancreatic beta cells $[10,11]$, but the significance of multivesicular release to insulin secretion remains unknown. Evidence for multivesicular release is particularly strong for electrically non-excitable cells $[6,7,12]$, but recent data indicate that it also occurs in intensely stimulated neurons [13]. In pancreatic beta cells, ultrastructural evidence indicates that granules can prefuse within the cell under certain experimental conditions [14], but attempts to demonstrate multivesicular exocytosis by live cell imaging have produced conflicting results $[10,15,16]$.

We have examined the occurrence of compound exocytosis in rat pancreatic beta cells by a combination of biophysical measurements, optical imaging and electron microscopy. Our data confirm that single-vesicle exocytosis is the predominant form of exocytosis in beta cells stimulated with glucose alone but that compound exocytosis becomes quantitatively significant under experimental conditions associated with global elevation of cytosolic $\mathrm{Ca}^{2+}$.

\section{Methods}

Islet isolation and cell culture All experiments were conducted in accordance with the UK Animals Scientific
Procedures Act (1986) and University of Oxford ethical guidelines. Pancreatic islets were isolated from SpragueDawley rats (Harlan, UK). For some experiments (see Figs 1, 2, 3, and 6), the islets were dissociated into single cells, plated on to plastic Petri dishes and maintained in short-term (up to $48 \mathrm{~h}$ ) tissue culture as previously reported [17], whereas intact islets were used for the remaining experiments.

$\mathrm{P} 2 \mathrm{X}_{2}$ current and capacitance measurements Parallel measurements of ATP release and change in membrane capacitance $\left(\Delta C_{\mathrm{m}}\right)$ were carried out using the standard whole-cell configuration as described previously [17]. Rat beta cells were infected with an adenoviral construct encoding a P2X purinoreceptor $2\left(\mathrm{P} 2 \mathrm{X}_{2} \mathrm{R}\right)$-green fluorescent protein fusion protein [17]. The membrane potential was, unless otherwise indicated, clamped at $-70 \mathrm{mV} . \Delta C_{\mathrm{m}}$ was calculated by averaging the capacitance measurements $750 \mathrm{~ms}$ before and after a $\mathrm{P} 2 \mathrm{X}_{2}$ current transient. For display, the current signal was filtered at $100 \mathrm{~Hz}$ to remove the sine wave. One series of experiments (see Fig. 3) was conducted using the perforated patch technique. In these experiments, the signal was filtered at $1 \mathrm{kHz}$ and digitised at $2 \mathrm{kHz}$. In another series of experiments (see Fig. 2D), changes in cell capacitance were monitored in uninfected cells (i.e. cells not expressing $\mathrm{P} 2 \mathrm{X}_{2} \mathrm{Rs}$ ) to allow the time course of ATP release to be compared with the increase in membrane capacitance. In the latter measurements, the temporal resolution was $1 \mathrm{~ms}$.

Two-photon imaging of exocytosis Rat pancreatic islets were superfused with extracellular medium containing the fluorescent polar tracer, sulforhodamine (SRB; $0.7 \mathrm{mmol} / \mathrm{l}$ ) $[18,19]$. SRB was excited in the two-photon mode at $830 \mathrm{~nm}$ using a Chameleon laser (Coherent, Santa Clara, CA, USA). Emitted light was collected through a PlanApochromat objective $\times 63 / 1.4$ Oil (Carl Zeiss, Jena, Germany) at 570-650 nm. The full-width-at-half-maximal fluorescence intensity of fluorescent spots recorded for microspheres (diameter 0.1-4.0 $\mu \mathrm{m}$; TetraSpeck; Invitrogen, Paisley, UK) was measured and plotted against their actual size [20] to estimate actual diameters of objects represented by the spots in the SRB measurements (i.e. granules undergoing exocytosis). The diameters of the fluorescent dots were estimated from a circle fit into the pixels with intensity values equal to or greater than full-width-at-half-maximal fluorescence intensity. The temporal characteristics of exocytotic events were determined in regions of interest.

Insulin secretion Insulin was determined by radioimmunoassay as described elsewhere [21]. Briefly, batches of eight to ten islets were preincubated in $1 \mathrm{ml} \mathrm{Krebs} \mathrm{Ringer} \mathrm{bicar-}$ bonate buffer supplemented with 1 or $20 \mathrm{mmol} / \mathrm{l}$ glucose for 
a

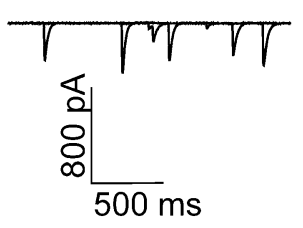

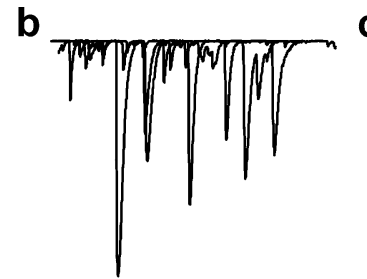
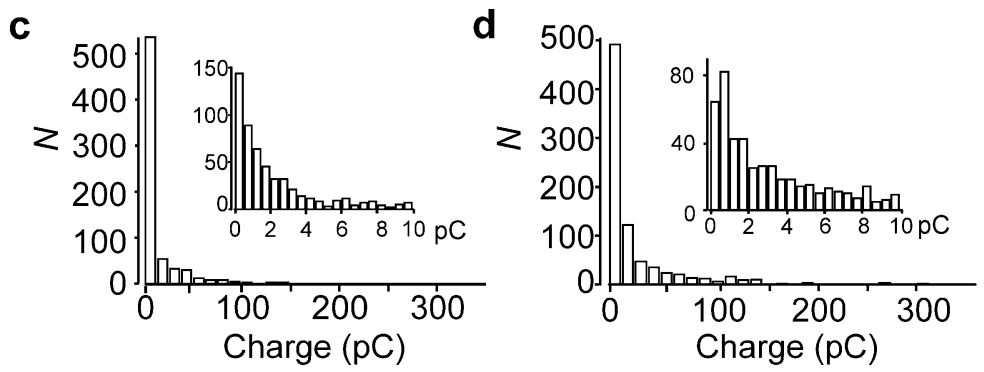

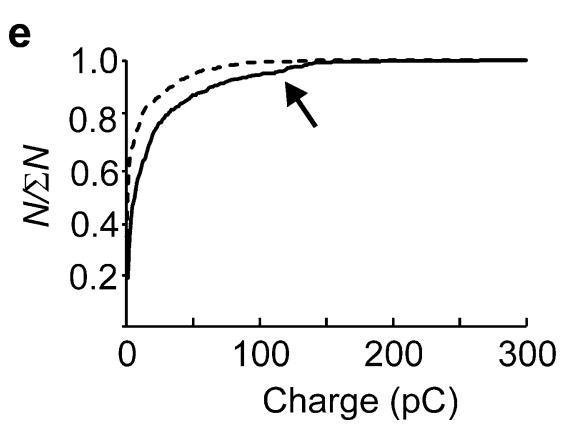

Fig. 1 Small and large release events detected in single rat beta cells expressing $\mathrm{P} 2 \mathrm{X}_{2}$ Rs. a,b ATP-induced $\mathrm{P} 2 \mathrm{X}_{2} \mathrm{R}$ current transients from rat beta cells infused with 0.2 (a) or 2 (b) $\mu \mathrm{mol} / 1\left[\mathrm{Ca}^{2+}\right]_{\mathrm{i}}$. Three sweeps have been superimposed in each panel. c,d Histograms of charge $(Q)$ of ATP-induced $\mathrm{P} 2 \mathrm{X}_{2} \mathrm{R}$ currents recorded at 0.2 (c) and 2 (d) $\mu \mathrm{mol} / 1\left[\mathrm{Ca}^{2+}\right]_{\mathrm{i}}$. Insets in c,d show events with $Q$-values $<10 \mathrm{pC}$. e Cumulative distribution $\left(N / \sum N\right)$ of the integrated current $(Q)$ of $\mathrm{P} 2 \mathrm{X}_{2} \mathrm{R}$ current spikes measured from rat beta cells infused with

$20 \mathrm{~min}$ followed by $1 \mathrm{~min}$ incubation in $1 \mathrm{ml}$ Krebs Ringer bicarbonate buffer containing 1 or $20 \mathrm{mmol} / \mathrm{l}$ glucose and $20 \mathrm{mmol} / \mathrm{l}$ glucose plus $20 \mu \mathrm{mol} / \mathrm{l}$ carbachol. At the end of the incubation, aliquots of the medium were removed and frozen pending the radioimmunoassay.

$\mathrm{Ca}^{2+}$ microfluorimetry and imaging Cytoplasmic free calcium concentration $\left(\left[\mathrm{Ca}^{2+}\right]_{\mathrm{i}}\right)$ in intact cells loaded with fura2AM ( $1 \mu \mathrm{mol} / \mathrm{l}$; Invitrogen) was monitored using a dualwavelength Photon Technology International (Birmingham, NJ, USA) system [22]. Confocal images were obtained using an upright Zeiss 510 confocal microscope after loading of isolated rat beta cells maintained in tissue culture with fluo-5AM ( $1 \mu \mathrm{mol} / \mathrm{l}$; Invitrogen) for $1 \mathrm{~h}$. Excitation was at $488 \mathrm{~nm}$, and emission measured at 510-540 nm.

FM1-43FX dye staining of exocytosis Isolated rat beta cells were superfused with extracellular medium containing $20 \mathrm{mmol} / \mathrm{l}$ glucose supplemented or not with carbachol $(20 \mu \mathrm{mol} / \mathrm{l})$ for $30 \mathrm{~s}$ in the presence of $5 \mu \mathrm{g} / \mathrm{ml} \mathrm{FM1-}$ 43FX (Invitrogen). The extracellular solution was quickly removed, the dish washed to remove excess dye, and the cells finally fixed in $4 \%$ paraformaldehyde at $4{ }^{\circ} \mathrm{C}$. Cells were scanned in $0.4 \mu \mathrm{m}$ z-slices using a Zeiss 510 confocal microscope (excitation $488 \mathrm{~nm}$; emission 515-550 nm).
Electron microscopy Islets were fixed in 4\% paraformaldehyde and $0.5 \%$ glutaraldehyde in phosphate buffer for $1 \mathrm{~h}$, post-fixed in $1 \%$ osmium tetroxide, dehydrated in methanol, and embedded in Epon 812 (Agar Scientific, Stansted, UK). Three-dimensional (3-D) electron micrographs $(50 \mathrm{~nm}$ section thickness) were obtained by microtome-scanning block face electron microscopy [23]. Images were acquired on an FEI Quanta 200 VP-FEG electron microscope using an accelerating voltage of $4 \mathrm{keV}$ and the low-vacuum mode $(0.5 \mathrm{~T})$ equipped with a microtome (3View; Gatan, Abingdon, UK). The contrasted specimen is cut inside the microscope. Every time the surface of the block is shaved off by a diamond knife, tissue is removed and the freshly cut surface of the block is scanned and an image is obtained. For transmission electron microscopy, ultrathin sections $(80 \mathrm{~nm})$ were cut on to Ni grids, contrasted with $2 \%$ uranyl acetate and lead citrate, and examined in a Jeol 1010 microscope (Welwyn Garden City, UK) with an accelerating voltage of $80 \mathrm{keV}$.

Solutions The standard extracellular solution used in all imaging and electrophysiology experiments contained (mmol/l) $138 \mathrm{NaCl}, 5.6 \mathrm{KCl}, 2.6 \mathrm{CaCl}_{2}, 1.2 \mathrm{MgCl}_{2}, 5$ Dglucose and 5 HEPES (pH 7.4 with $\mathrm{NaOH}$ ). For the $\mathrm{P}_{2} \mathrm{X}_{2} \mathrm{R}$ experiments, the intracellular (pipette) solution consisted of (mmol/l) $125 \mathrm{CsCl}, 10 \mathrm{NaCl}, 1 \mathrm{MgCl}_{2}, 10 \mathrm{EGTA}, 5$ or 9 
a
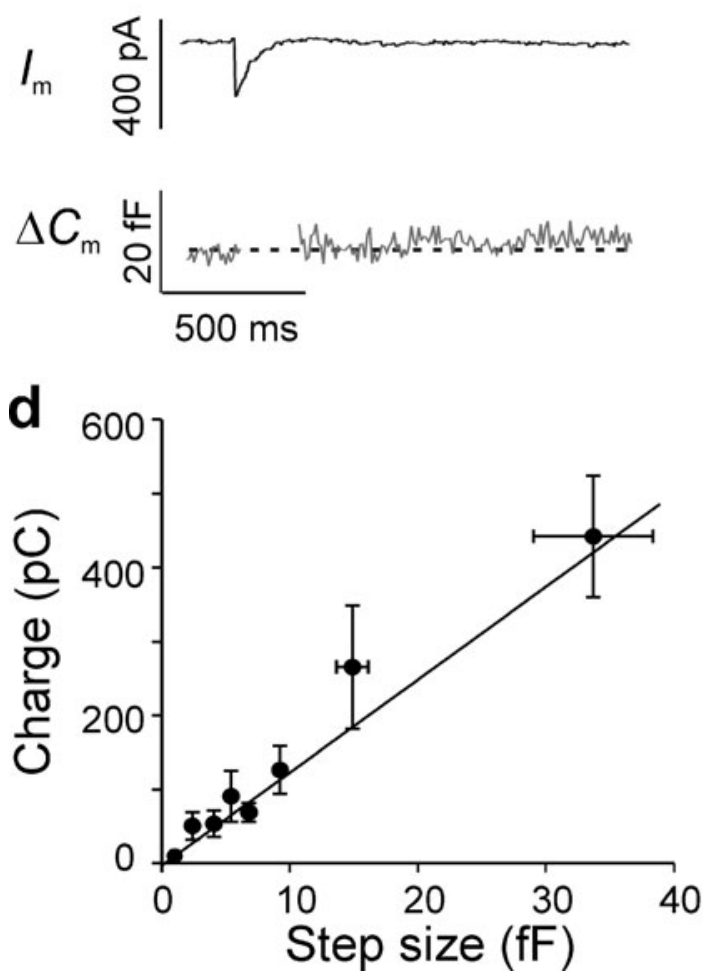

Fig. 2 Large $\mathrm{P} 2 \mathrm{X}_{2} \mathrm{R}$ events correlate with large increases in membrane capacitance in single rat beta cells. a,b Representative examples of parallel measurements of $\mathrm{P} 2 \mathrm{X}_{2} \mathrm{R}$ currents $\left(I_{\mathrm{m}}\right)$ and membrane capacitance $\left(\Delta C_{\mathrm{m}}\right)$ for small (a) and large (b) events. Note that the currents rise and fall monotonically. Activation of $\mathrm{P} 2 \mathrm{X}_{2} \mathrm{Rs}$ results in large increases in membrane conductance that 'leaks' into the capacitance signal, and these parts of the experimental record have been removed. c As in $\mathbf{a}, \mathbf{b}$, but showing an example where a step increase in capacitance was associated with a series of discrete superimposed current spikes (arrows) reflecting exocytosis of individual granules. d Relationship between the integrated $\mathrm{P} 2 \mathrm{X}_{2} \mathrm{R}$-mediated current $(Q)$ and the associated

$\mathrm{CaCl}_{2}, 3 \mathrm{MgATP}, 0.1 \mathrm{cAMP}$ and 5 HEPES (pH 7.15 using $\mathrm{CsOH}) .\left[\mathrm{Ca}^{2+}\right]_{\mathrm{i}}$ was estimated to be 0.2 and $2 \mu \mathrm{mol} / 1 \mathrm{using}$ the WIN MAXC32 2.5 computer program [24]. For the perforated patch recordings (see Fig. 3), the recording electrode contained (mmol/l) $76 \mathrm{~K}_{2} \mathrm{SO}_{4}, 10 \mathrm{NaCl}, 10 \mathrm{KCl}, 1$ $\mathrm{MgCl}_{2}$ and 5 HEPES ( $\mathrm{pH} 7.35$ with $\mathrm{KOH}$ ). In the latter experiments, endogenous $\mathrm{Ca}^{2+} /$ calmodulin-dependent protein kinase 2 (CAMKII) was inhibited by preincubating the cells for $2 \mathrm{~h}$ in the presence of $20 \mu \mathrm{mol} / 1$ of the myristoylated CAMKII autoinhibitory peptide (Biomol International, Exeter, UK).

Data analysis Data are presented as mean values \pm SEM. Statistical significances of differences between means and distributions were estimated by Student's $t$ test or by Kolmogorov-Smirnov's test (cumulative histograms). The 3-D reconstruction of the FM1-43FX events was performed using the Imaris 6.1.5 software (Bitplane Scientific
C

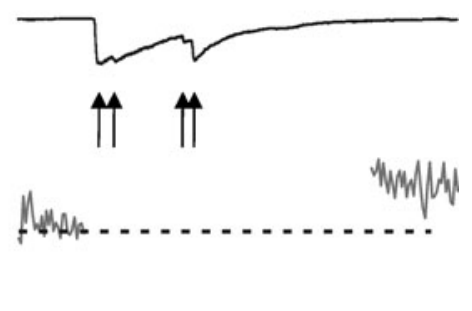

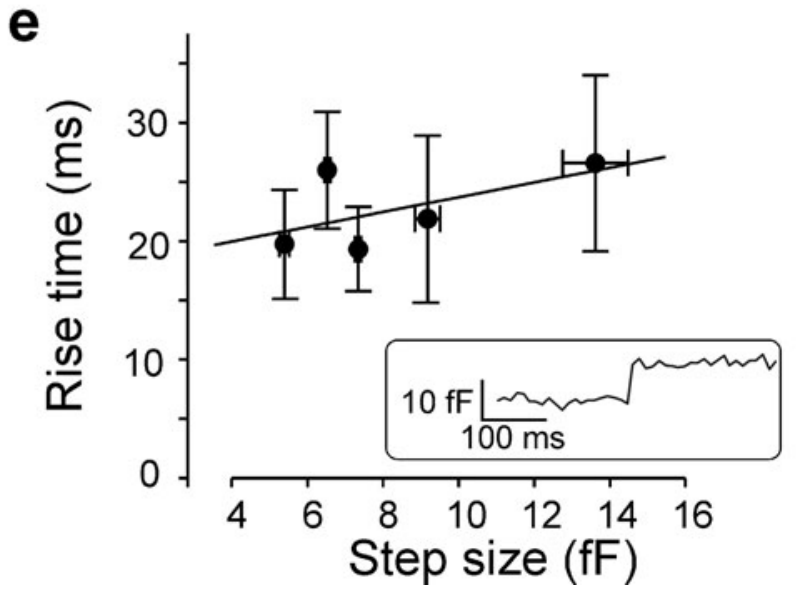

capacitance increase $\left(\Delta C_{\mathrm{m}}\right)$ in rat beta cells. The regression coefficient ( $r)$ was $0.79(p<0.001)$. e Relationship between size of capacitance steps $\left(\Delta C_{\mathrm{m}}\right)$ and time to reach the new plateau value recorded in nontransfected cells but conditions otherwise as in a-d. Inset shows an example of an exocytotic event with an amplitude of $18 \mathrm{fF}$ (simultaneous fusion of five or six granules). Note that this analysis only includes large events and that events $<4 \mathrm{fF}$ (reflecting single exocytotic events) cannot be resolved during whole-cell recordings. For display purposes, individual data points have been grouped according to $\Delta C_{\mathrm{m}}$ in $\mathbf{d}$ and $\mathbf{e}$ ( $n=48$ and 47 , respectively)

Solutions, Zurich, Switzerland). The $\mathrm{P} 2 \mathrm{X}_{2} \mathrm{R}$-dependent current spikes were analysed using the Mini Analysis Program 6.0.3 (Synaptosoft, Decatur, GA, USA). The confocal $\left[\mathrm{Ca}^{2+}\right]_{\mathrm{i}}$ (Fig. 3B) and optical measurements of secretion (Figs 4 and 5) were analysed and presented using the software LSM Image Examiner. The numerical data of the exocytotic events thus measured were imported into MATLAB to determine the $t_{10-90 \%}$ and half widths (HWs; Fig. 5).

\section{Results}

Magnitude of quantal ATP release increases in response to elevated $\left[\mathrm{Ca}^{2+}\right]_{i}$ Insulin secretion is associated with ATP release [17]. Figure 1a,b shows examples of ATP-evoked currents (reflecting exocytosis) recorded from rat beta cells infected with $\mathrm{P} 2 \mathrm{X}_{2} \mathrm{Rs}$ and infused with 0.2 or 
a

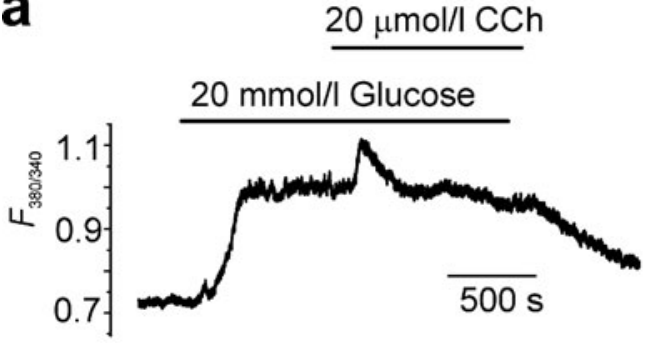

d

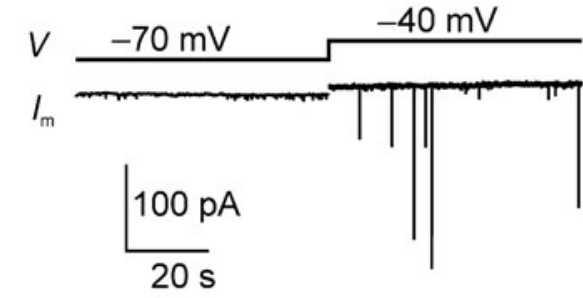

g

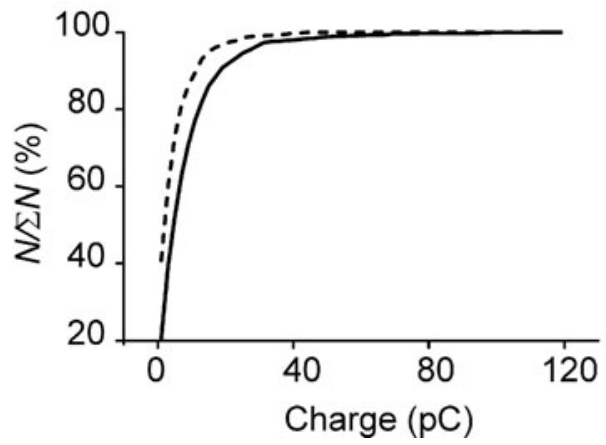

Fig. 3 Carbachol-induced compound exocytosis in single rat beta cells. a Fura- 2 measurements of $\left[\mathrm{Ca}^{2+}\right]_{\mathrm{i}}$ in an intact rat islet stimulated with $20 \mathrm{mmol} / 1$ glucose and $20 \mu \mathrm{mol} / 1$ carbachol $(\mathrm{CCh})$ as indicated by horizontal lines. b,c Fluo-5 recording of $\left[\mathrm{Ca}^{2+}\right]_{\mathrm{i}}(F[$ in arbitrary units, a.u.]) in a rat beta cell exposed to $20 \mathrm{mmol} / \mathrm{l}$ glucose before and after addition of $20 \mu \mathrm{mol} / \mathrm{l}$ carbachol as indicated (b) and confocal ('2.5D') image of the same isolated rat beta cell showing the fluorescence increase $(\Delta F)$ evoked by application of $20 \mu \mathrm{mol} / \mathrm{l}$ carbachol (c) obtained by subtracting image immediately before addition of carbachol from that obtained at the peak (representative of five different cells). The dotted line in $\mathbf{c}$ indicates the circumference of the beta cell. $\mathbf{d}$ ATP release in rat beta cells (measured as activation of $\mathrm{P} 2 \mathrm{X}_{2} \mathrm{Rs}$ )

$2 \mu \mathrm{mol} / 1\left[\mathrm{Ca}^{2+}\right]_{\mathrm{i}}$. These currents reflect activation of the $\mathrm{P} 2 \mathrm{X}_{2} \mathrm{Rs}$ and are blocked by the purinergic antagonist, suramin [25]. At low $\left[\mathrm{Ca}^{2+}\right]_{\mathrm{i}}$, the events are infrequent and small $(<300 \mathrm{pA})$. Elevation of $\left[\mathrm{Ca}^{2+}\right]_{\mathrm{i}}$ to $2 \mu \mathrm{mol} / 1$ increases the frequency, amplitude and duration of these events. Figure 1c,d shows the histograms for the integrated currents $(Q)$ of the events recorded at 0.2 and $2 \mu \mathrm{mol} / 1\left[\mathrm{Ca}^{2+}\right]_{\mathrm{i}}$; nonGaussian (skewed) distributions were obtained under both experimental conditions (see electronic supplementary material [ESM] text, section 1). Whereas most events recorded at low $[\mathrm{Ca}]_{\mathrm{i}}$ were smaller than $5 \mathrm{pC}, \sim 55 \%$ of the events recorded
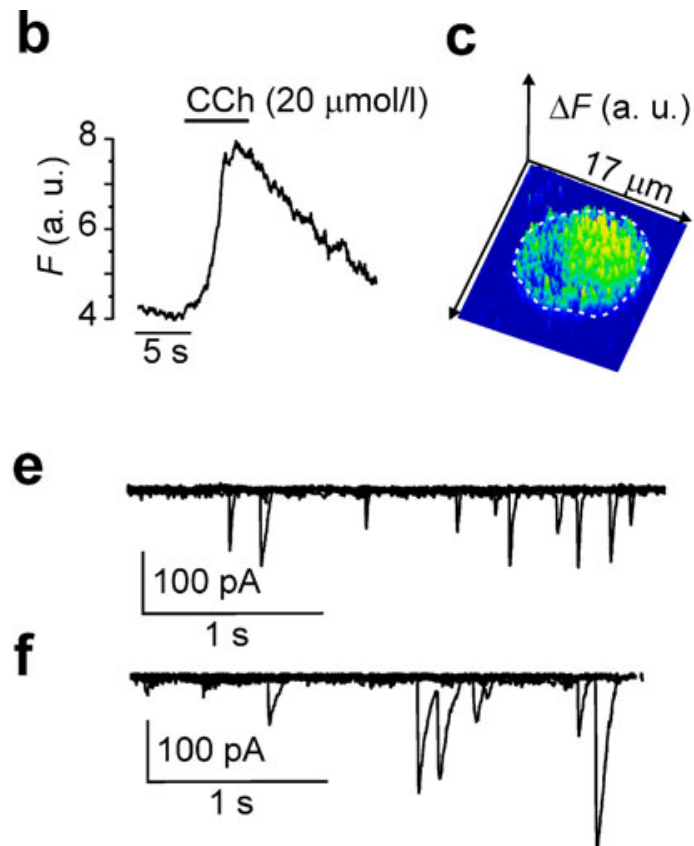

h

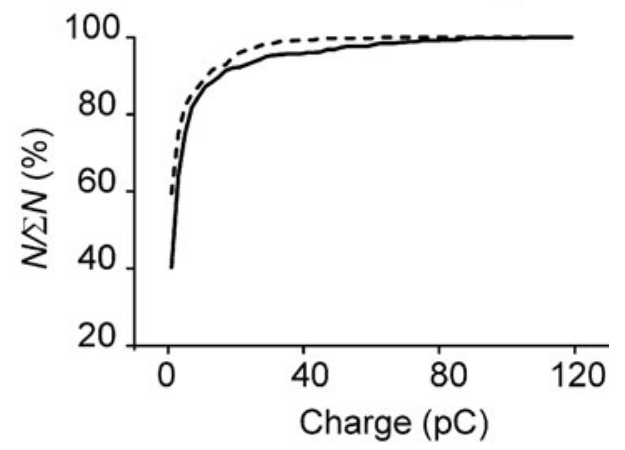

under control conditions ( $10 \mathrm{mmol} / \mathrm{l}$ glucose alone) when cell was held at $-70 \mathrm{mV}$ and after moderate depolarisation to $-40 \mathrm{mV}$. Note stimulation of exocytosis seen as emergence of current transients. e,f ATP release measured at $-40 \mathrm{mV}$ in rat beta cells exposed to $10 \mathrm{mmol} / 1$ glucose in the absence (e) or presence (f) of $20 \mu \mathrm{mol} / 1$ carbachol. Several sweeps have been superimposed. g Cumulative distribution $(N / \Sigma N)$ of charge $(Q)$ recorded in the presence of $10 \mathrm{mmol} / \mathrm{l}$ glucose alone (dashed line; 836 events) and in the presence of $20 \mu \mathrm{mol} / 1$ carbachol (continuous line; 1,234 events). $\mathbf{h}$ As in $\mathbf{g}$ but after pretreatment of the cells with $20 \mu \mathrm{mol} / 1$ of the myristoylated CAMKII autoinhibitory peptide for $2 \mathrm{~h}$ (glucose: 448 events; glucose+carbachol: 603 events)

at $2 \mu \mathrm{mol} / 1\left[\mathrm{Ca}^{2+}\right]_{\mathrm{i}}$ were larger than $5 \mathrm{pC}$. The corresponding cumulative histograms are shown in Fig. 1e. The distribution of the $Q$ of exocytotic events was shifted to the right when $\left[\mathrm{Ca}^{2+}\right]_{\mathrm{i}}$ was elevated from 0.2 to $2 \mu \mathrm{mol} / 1(p<0.001)$.

Figure $1 \mathrm{f}$ shows the relationship between charge and the $t_{10-90 \%}$ and HW. The $t_{10-90 \%}$ values were $<10 \mathrm{~ms}$ over a wide range of $Q$. By contrast, the HWs increased with the event size: from $\sim 10 \mathrm{~ms}$ for small events to $\sim 40 \mathrm{~ms}$ for events $>50$ pC (Fig. 1g). A longer duration of the ATP-induced $\mathrm{P} 2 \mathrm{X}_{2} \mathrm{R}$ current would be consistent with the emptying of an enlarged granule lumen, which may result if several 


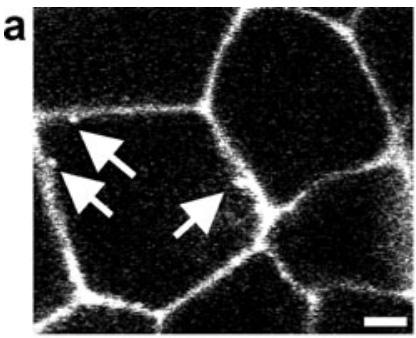

b

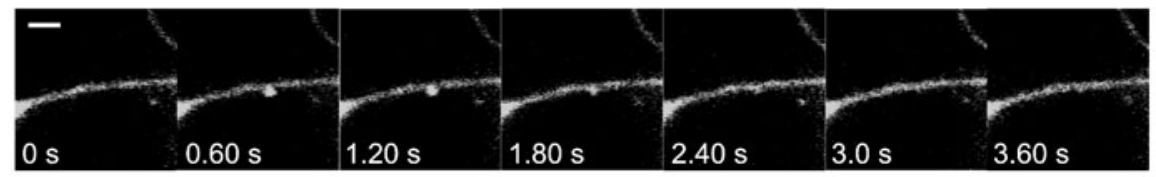

C

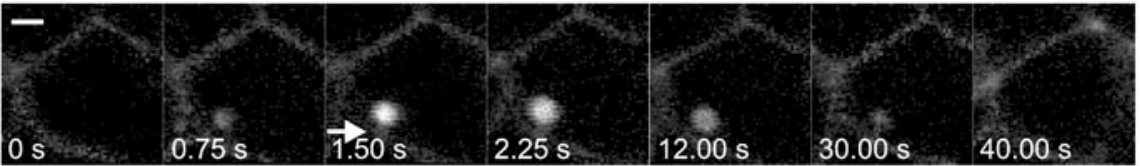

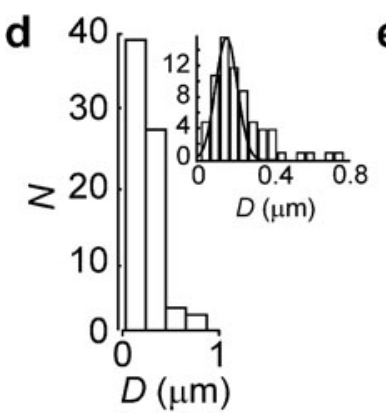
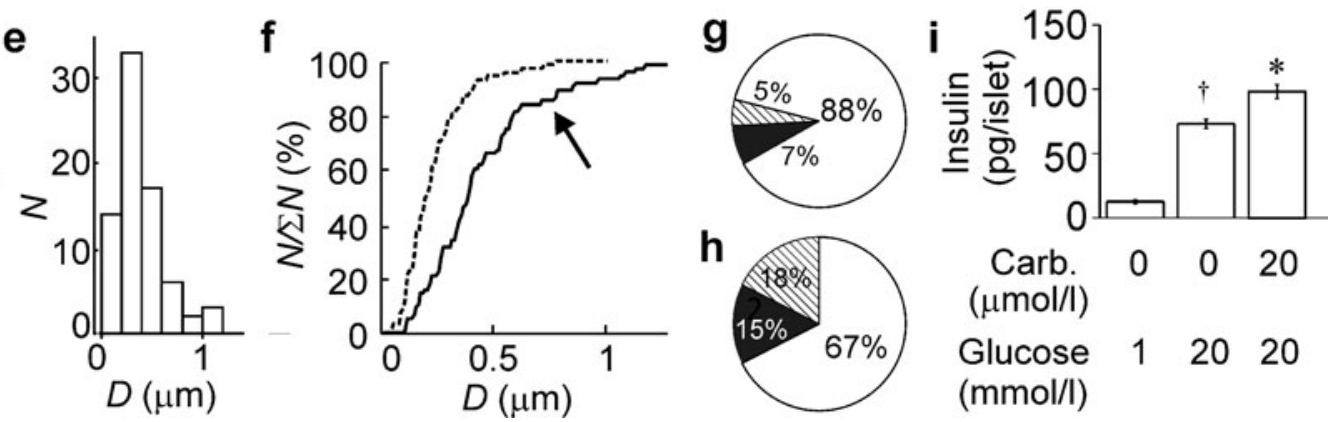

Fig. 4 Optical imaging of exocytosis in intact rat islets. a Two-photon excitation microscopy of an intact pancreatic islet perfused with an extracellular solution containing the fluorescent polar tracer SRB $(0.7 \mathrm{mmol} / \mathrm{l})$ and $20 \mathrm{mmol} / \mathrm{l}$ glucose. Scale bar: $3 \mu \mathrm{m}$. The three arrows indicate exocytotic events. b,c Example of a typical single event (b) and a large event (c) in the presence of $20 \mathrm{mmol} / \mathrm{l}$ glucose and $20 \mu \mathrm{mol} / 1$ carbachol. Scale bar: $1 \mu \mathrm{m}$. Images were taken at the indicated times (relative to the leftmost image). Note that the large event in c appears within the cell and is connected to the exterior by a stalk (dim fluorescence, arrow). d Histogram of diameters $(D)$ of the fluorescent spots reflecting exocytosis in the presence of glucose. The inset shows the distribution on an expanded abscissa. A Gaussian curve with a mean value of $0.23 \mu \mathrm{m}$ has been superimposed (102 events, 8 islets). e As in $\mathbf{d}$ but showing distribution after addition of

$20 \mu \mathrm{mol} / 1$ carbachol (100 events, 8 islets). f The same data plotted as the cumulative distribution $\left(N / \sum N\right)$ of the diameters of exocytotic events evoked by $20 \mathrm{mmol} / \mathrm{l}$ glucose alone (dashed line) and $20 \mathrm{mmol} / 1$ glucose $+20 \mu \mathrm{mol} / 1$ carbachol (continuous line). Note inflection at $\sim 0.5 \mu \mathrm{m}$ on distribution of events collected in the presence of carbachol (arrow). g,h Pie charts summarising relative frequency of single-vesicle (white), sequential (black) and multivesicular (hatched) exocytosis in beta cells within intact rat islets exposed to $20 \mathrm{mmol} / 1$ glucose with (h) or without (g) $20 \mu \mathrm{mol} / 1$ carbachol. The data were collected in 13 different islets and based on a total observation period of $>3,100 \mathrm{~s}$ for each condition. $\mathbf{i}$ Insulin secretion measured in the presence of 1 or $20 \mathrm{mmol} /$ glucose during a $1 \mathrm{~min}$ incubation. Carbachol $(20 \mu \mathrm{mol} / \mathrm{l}$; Carb.) was included as indicated. ${ }^{*} p<0.005$ vs $20 \mathrm{mmol} / 1$ glucose alone; $\uparrow p<0.001$ vs $1 \mathrm{mmol} / 1$ glucose

granules combine within the cell and then fuse with the plasma membrane as one unit (multivesicular exocytosis) or rapid sequential exocytosis emptying via a single fusion pore.

If multivesicular exocytosis occurs, then there should be a correlation between the $Q$ and the amount of membrane added (measured as $\Delta C_{\mathrm{m}}$ ). Figure 2a,b shows examples of events associated with small and large $\mathrm{P} 2 \mathrm{X}_{2} \mathrm{R}$ currents and parallel $\Delta C_{\mathrm{m}}$ in rat beta cells dialysed with $0.2 \mu \mathrm{mol} / 1\left[\mathrm{Ca}^{2+}\right]_{\mathrm{i}}$. In both cases, the ATP-evoked wholecell currents rose and decayed monotonically with no sign of superimpositions of discrete events. Statistical analysis suggests that it is highly unlikely that these events result from superimposition of multiple smaller events (ESM text, section 2). For comparison, Fig. 2c shows an example where a step capacitance increase of $\sim 10 \mathrm{fF}$ is associated with four discrete spikes that are superimposed. Thus we can estimate that each release event adds $\sim 2.5 \mathrm{fF}$ of capacitance, close to the $2.9 \mathrm{fF}$ measured by on-cell capacitance measurements [26]. Figure $2 \mathrm{~d}$ shows the relationship between $\Delta C_{\mathrm{m}}$ and $Q$ (only including events without signs of superimpositions).
The largest steps averaged $\sim 35 \mathrm{fF}$, corresponding to the simultaneous fusion of more than ten granules with the plasma membrane.

It would appear that the increase in capacitance (reflecting the fusion of the granules with the plasma membrane) should precede the emptying of the granules (detected as the activation of the $\mathrm{P} 2 \mathrm{X}_{2} \mathrm{Rs}$ ). However, intragranular ATP is highly mobile and exits promptly upon membrane fusion, even before complete expansion of the fusion pore [26-29]. It is accordingly not possible to temporally dissociate the capacitance increase from ATP release. Indeed, the capacitance steps recorded in beta cells not infected with $\mathrm{P} 2 \mathrm{X}_{2} \mathrm{Rs}$ exhibited a kinetics (rise time $\sim 20 \mathrm{~ms}$; Fig. 2e) that was, if anything, slower than that of the events recorded with the $\mathrm{P} 2 \mathrm{X}_{2} \mathrm{R}$-based assay (cf. Fig. 1f). It can also be noted, however, that the large $\Delta C_{\mathrm{m}}$ steps develop with a time course only marginally slower than that seen for the small steps, a feature not consistent with the notion that they result from rapid sequential exocytosis of individual secretory granules. 
a
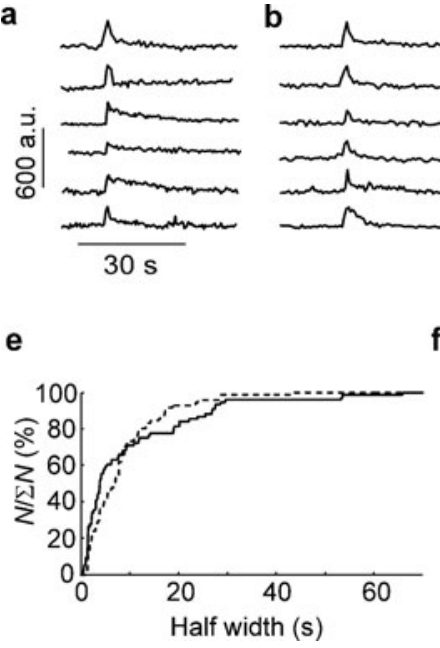

Fig. 5 Kinetics of exocytosis in beta cells within intact rat pancreatic islets. a,b Examples of fluorescent intensity changes associated with events recorded in the presence of $20 \mathrm{mmol} / \mathrm{l}$ glucose alone (a) and in the simultaneous presence of glucose $(20 \mathrm{mmol} / \mathrm{l})$ and carbachol $(20 \mu \mathrm{mol} / \mathrm{l})(\mathbf{b})$ as indicated. c Examples of changes in fluorescence associated with the larger events observed in the presence of carbachol. Traces in $\mathbf{a}-\mathbf{c}$ are shown using the same timebase and ordinate scales. d Relationship between diameter $(D)$ of exocytotic events and rise time $\left(t_{10-90 \%}\right)$ recorded in the presence of $20 \mathrm{mmol} / \mathrm{l}$ glucose alone (white circles) and after supplementation of medium with $20 \mu \mathrm{mol} / 1$ carbachol (black squares). For clarity, the individual data points have been grouped according to size. e Cumulative distribution $(N / \Sigma N)$ of the

Carbachol stimulates compound exocytosis in rat beta cells The findings of Fig. 1 indicate that a global elevation of $\left[\mathrm{Ca}^{2+}\right]_{\mathrm{i}}$ (by intracellular dialysis via the recording electrode) promotes multivesicular release. Acetylcholine stimulates insulin secretion by activation of muscarinic M3 receptors [30] and enhances insulin release through a combination of several effects [31] including activation of protein kinase $\mathrm{C}(\mathrm{PKC})$ and inositol trisphosphate $\left(\mathrm{IP}_{3}\right)$ dependent mobilisation of intracellular $\mathrm{Ca}^{2+}[32,33]$. Figure 3a shows changes in $\left[\mathrm{Ca}^{2+}\right]_{\mathrm{i}}$ evoked by $20 \mathrm{mmol} / 1$ glucose alone and after addition of $20 \mu \mathrm{mol} / 1$ carbachol in an intact rat pancreatic islet. Glucose produces a nonoscillatory elevation of $\left[\mathrm{Ca}^{2+}\right]_{\mathrm{i}}$, and carbachol elicits a transient further elevation. We confirmed by confocal imaging of $\left[\mathrm{Ca}^{2+}\right]_{i}$ (in agreement with previous reports [34]) that carbachol elicited a widespread increase in $\left[\mathrm{Ca}^{2+}\right]_{\mathrm{i}}$ in the cell centre (Fig. 3b,c).

We monitored exocytosis before and after the addition of $20 \mu \mathrm{mol} / \mathrm{l}$ carbachol to individual rat beta cells infected with $\mathrm{P} 2 \mathrm{X}_{2} \mathrm{Rs}$ using the perforated patch whole-cell technique. The cells were exposed to $10 \mathrm{mmol} / \mathrm{l}$ glucose and the membrane potential initially held at $-70 \mathrm{mV}$ to keep the voltagegated $\mathrm{Ca}^{2+}$ channels closed. Under these conditions, the rate of exocytosis was low, and $\mathrm{P} 2 \mathrm{X}_{2} \mathrm{R}$ currents not observed. Depolarisation to $-40 \mathrm{mV}$ resulted in sufficient activation of
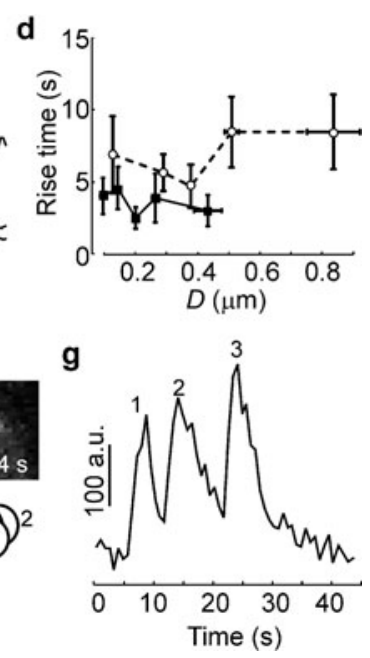

rise times $\left(t_{10-90 \%}\right)$ of the fluorescence increases associated with exocytosis observed in the presence of $20 \mathrm{mmol} / 1$ glucose alone (71 events in 7 islets; dashed line) and $20 \mathrm{mmol} / 1$ glucose plus $20 \mu \mathrm{mol} / 1$ carbachol (76 events in six islets; continuous line). f Montage of images during an example of sequential exocytosis in a rat beta cell exposed to $20 \mathrm{mmol} / 1$ glucose and $20 \mu \mathrm{mol} / \mathrm{l}$ carbachol. Images were taken at the indicated times (relative to the one in the upper left corner). Scale bar: $1 \mu \mathrm{m}$. The three circles in the lower right corner indicate the position of the 1 st, 2 nd and 3rd release events (expanded $\times 2.5$ ) shown in the montage. Note that they occur in close proximity to each other but not in exactly the same place. $\mathbf{g}$ Time course of SRB fluorescence increase of events 1-3 shown in $\mathbf{f}$. a.u., arbitrary units

the $\mathrm{Ca}^{2+}$ channels to initiate exocytosis (Fig. 3d). Figure $3 \mathrm{e}, \mathrm{f}$ shows examples of the $\mathrm{P} 2 \mathrm{X}_{2} \mathrm{R}$ currents elicited at $-40 \mathrm{mV}$ in the presence of glucose alone and after addition of carbachol. It is evident that addition of carbachol increases the amplitude and duration of the events, but their frequency was not affected $(0.22 \pm 0.05$ events/s and $0.17 \pm 0.04$ events $/ \mathrm{s}$ in the absence and presence of carbachol, respectively). The cumulative histograms of $Q$ in the absence and presence of carbachol are shown in Fig. 3g. The distribution was shifted to the right in the presence of $20 \mu \mathrm{mol} / 1$ carbachol $(p<$ 0.001). The effects of carbachol cannot be attributed to changes in the gating of the $\mathrm{P} 2 \mathrm{X}_{2} \mathrm{R}$ currents; the integrated current evoked by application of $30 \mu \mathrm{mol} / \mathrm{l}$ ATP in the presence of $20 \mu \mathrm{mol} / 1 \mathrm{carbachol}$ averaged $101 \pm 8 \%(n=4)$ of that evoked in the absence of the agonist. The effect of carbachol was not mimicked by application of the PKC activator phorbol 12-myristate 13-acetate (PMA; $162 \mathrm{nmol} / \mathrm{l}$, not shown), was insensitive to the PKC inhibitor chelerythrine $(1.3 \mu \mathrm{mol} / 1$; not shown), but partially antagonised by pretreatment of the cells with $20 \mu \mathrm{mol} / 1$ the myristoylated CAMKII autoinhibitory peptide (Fig. 3h).

Optical imaging of multivesicular exocytosis in beta cells in intact islets We investigated the occurrence of multivesicular exocytosis in beta cells within intact pancreatic islets using 

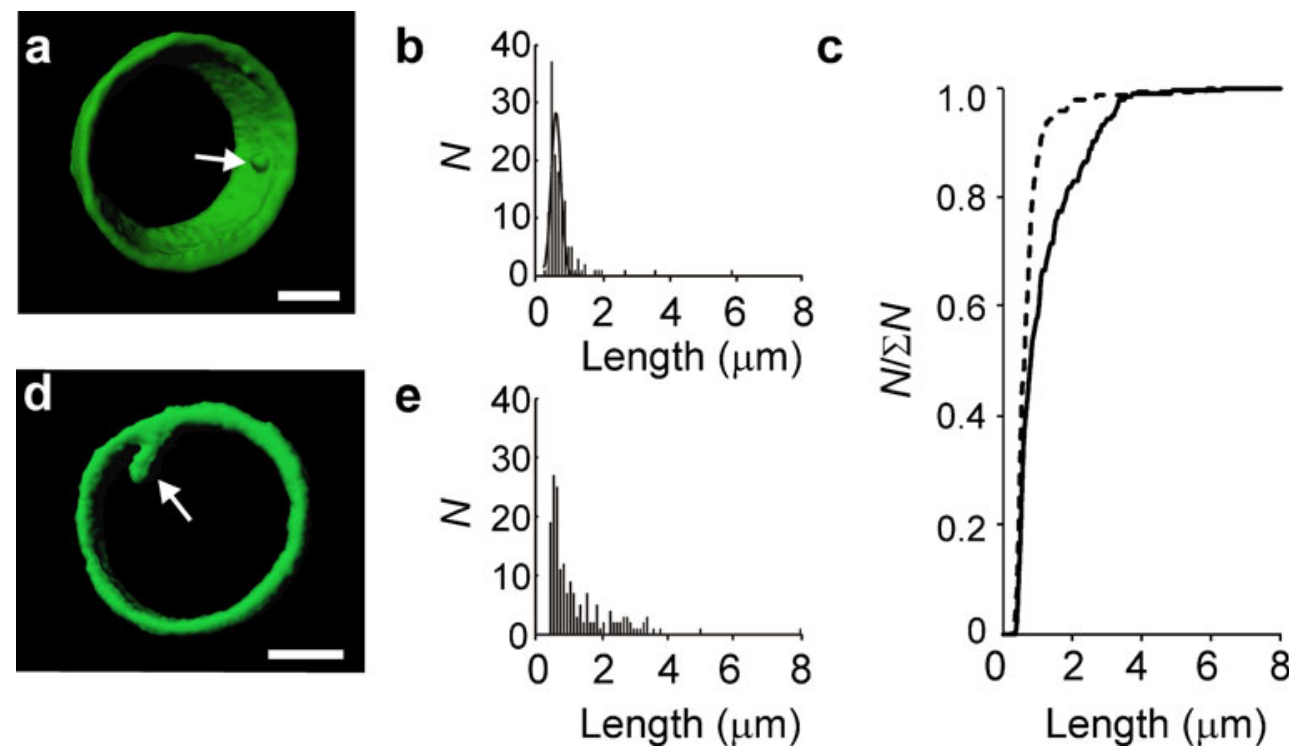

Fig. 6 Multivesicular exocytosis detected by confocal imaging in isolated rat beta cells. a 3-D reconstruction of exocytotic events observed in rat beta cells captured during $30 \mathrm{~s}$ exposures to FM1-43FX in the presence of $20 \mathrm{mmol} / \mathrm{l}$ glucose alone. b Histogram of diameters/ lengths of FM1-43FX-labelled structures in cells stimulated with $20 \mathrm{mmol} / 1$ glucose alone. A Gaussian curve with a peak at $0.60 \mu \mathrm{m}$ has been superimposed on distribution. c Cumulative distribution of structures labelled by FM1-43FX in the presence of glucose alone (dashed line; $n=140$ in 70 cells) and when combined with carbachol (continuous line; $n=176$ in 40 cells). $\mathbf{d}$ As in a but showing an example of a large event observed in the simultaneous presence of $20 \mathrm{mmol} / \mathrm{l}$ glucose and $20 \mu \mathrm{mol} / \mathrm{l}$ carbachol. e As in b but showing histogram of diameters/lengths of FM1-43FX-labelled structures in cells stimulated with the combination of $20 \mathrm{mmol} / \mathrm{l}$ glucose and $2 \mu \mathrm{mol}$ carbachol
SRB imaging. Figure 4a shows a region of an islet exposed to $20 \mathrm{mmol} / \mathrm{l}$ glucose. Exocytotic events were identified as the rapid appearance of fluorescent spots with a diameter of $>0.15 \mu \mathrm{m}$ that are easily distinguished from endocytotic events, most of which have diameters of $<0.08 \mu \mathrm{m}$ [35, $36]$. The arrows highlight three exocytotic events. The islet was subsequently exposed to $20 \mu \mathrm{mol} / 1$ carbachol in the continued presence of $20 \mathrm{mmol} / \mathrm{l}$ glucose. Figure $4 \mathrm{~b}, \mathrm{c}$ shows magnified views of small and large events observed during carbachol stimulation. The larger event appeared within the cell and seemed connected to the extracellular space via a stalk of dim fluorescence.

The distribution of the corrected diameters of the fluorescent spots seen in the presence of glucose alone and in the simultaneous presence of glucose and carbachol are shown in Fig. 4d,e. The events evoked by $20 \mathrm{mmol} / \mathrm{l}$ glucose alone had a diameter of $0.23 \pm 0.02 \mu \mathrm{m}$, in reasonable agreement with that estimated for insulin granules by electron microscopy [37]. The cumulative distributions of the diameters observed at $20 \mathrm{mmol} / \mathrm{l}$ glucose alone and after supplementation of the medium with $20 \mu \mathrm{mol} / \mathrm{l}$ carbachol are shown in Fig. 4f; the distribution is shifted to the right in the presence of carbachol $(p<0.001)$. In the presence of carbachol, $15 \%$ of the events were larger than any of the events observed in the presence of glucose. The diameter of this subgroup of events averaged $1.20 \pm 0.23 \mu \mathrm{m}, 5.2$-fold larger than the average of the events evoked by glucose alone. The frequency of exocytosis increase averaged 2.4 events/min per islet in both the absence and presence of carbachol in islets exposed to $20 \mathrm{mmol} / \mathrm{l}$ glucose (not shown). However, the fraction of events that were of the compound type increased $>3.5$-fold, from $5 \%$ in the presence of $20 \mathrm{mmol} / 1$ glucose alone (Fig. $4 \mathrm{~g}$ ) to $18 \%$ after addition of $20 \mu \mathrm{mol} / \mathrm{l}$ carbachol (Fig. $4 \mathrm{~h}$ ). In islets exposed to $20 \mathrm{mmol} / \mathrm{l}$ glucose, a $1 \mathrm{~min}$ stimulation with $20 \mu \mathrm{mol} / \mathrm{l} \mathrm{car}$ bachol stimulated insulin secretion by $35 \%$ (Fig. 4i). The corresponding stimulation measured over $20 \mathrm{~min}$ averaged $49 \%$ (not shown). In islets exposed to $1 \mathrm{mmol} / 1$ glucose throughout, insulin secretion was $<20 \%$ of that seen in the presence of glucose.

Representative recordings of the SRB fluorescence changes in the presence of glucose alone and when the medium was supplemented with carbachol are shown in Fig. 5a,b. Most events recorded in the presence of carbachol were of the same size as those observed with glucose alone. Occasionally, however, much larger events were observed (Fig. 5c). These large events increased monotonically without any irregularities suggestive of smaller events being superimposed. The relationship between the diameter of the event and the rise times is shown in Fig. 5d. Under control conditions $(20 \mathrm{mmol} / \mathrm{l}$ glucose $)$, the rise times of events averaged $3.9 \pm 0.6 \mathrm{~s}$ and did not vary much with the diameter. In the presence of carbachol, events with a diameter of $<0.4 \mu \mathrm{m}$ (similar to those evoked by glucose alone) had a mean rise time of $5.10 \pm 1.20 \mathrm{~s}$. However, for larger events the rise time increased to $9.1 \pm 1.6 \mathrm{~s}(p<0.001 \mathrm{vs}$ all events at 
a
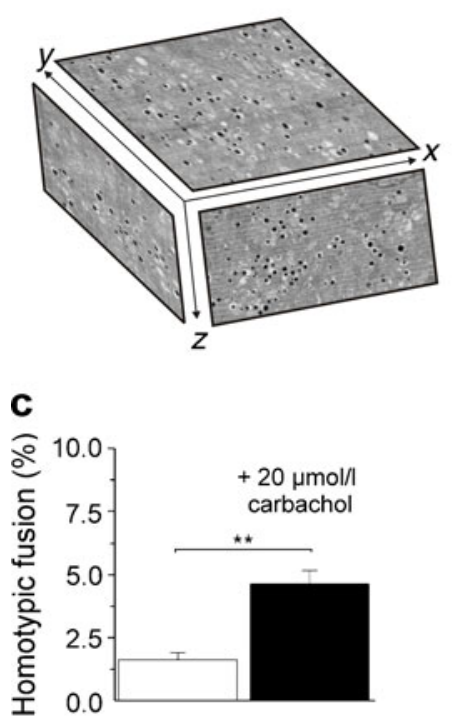

b

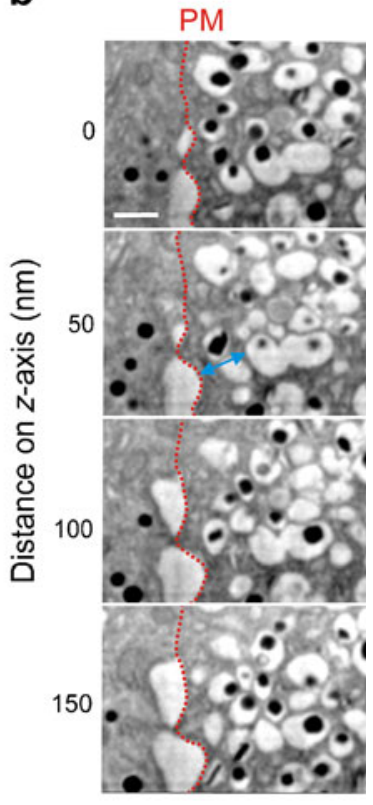

d

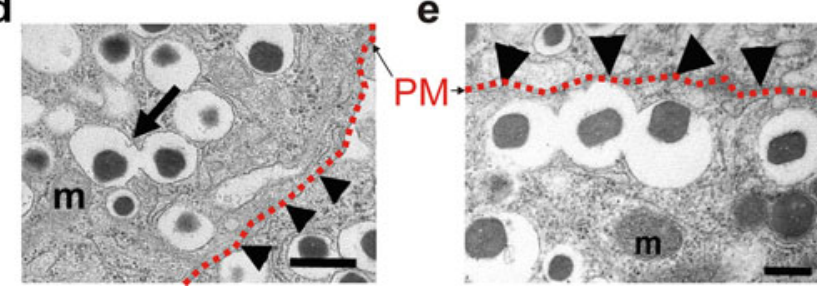

Fig. 7 Ultrastructural evidence for multigranular structures in beta cells captured by 3-D and two-dimensional electron microscopy in the presence of glucose or glucose plus the cholinergic agonist carbachol in intact islets. a Schematic representation of a 3-D block of a serially sectioned rat pancreatic islet. b Serial sections of a single beta cell exposed to the cocktail of glucose $(20 \mathrm{mmol} / \mathrm{l})$ and carbachol $(20 \mu \mathrm{mol} / \mathrm{l} ; 5 \mathrm{~min})$. Images illustrate a group of homotypically fused granules with connected cores. Note that the captured multivesicular complex is approximately one granule diameter (blue double-headed arrow) from the plasma membrane (PM, red dotted line). Section thickness: $50 \mathrm{~nm}$. Scale bar: $0.4 \mu \mathrm{m}$. c The percentage of homotypically fused granules relative to the total number of granules observed within the cytosol of four complete beta cells using the 3-D electron microscopic images in $20 \mathrm{mmol} / 1$ glucose alone ( $n=3,338$ granules) and when medium was supplemented with $20 \mu \mathrm{mol} / 1$ carbachol $(n=4,580$ granules); $* * p<0.01$. d,e Transmission electron microscopy (two-dimensional) examples of two individual multigranular structures in a rat beta cell exposed to $20 \mathrm{mmol} / \mathrm{l}$ glucose in the presence (d) and absence (e) of $20 \mu \mathrm{mol} / \mathrm{l}$ carbachol. Note that in $\mathbf{e}$ the multivesicular structure aligns below the plasma membrane (cf. Fig. 6d). The frequency of multivesicular structures was $0.18 \%$ (seven compound and 2,712 single events) and $0.37 \%$ (16 compound and 4,094 single events) in the absence and presence of carbachol, respectively. Data were from $\geq 25$ cells for both experimental conditions. The plasma membrane (PM) is indicated by the dotted red lines and arrow heads. Scale bars: $0.5 \mu \mathrm{m}$ in $\mathbf{d}$ and $0.2 \mu \mathrm{m}$ in e. A few mitochondria $(\mathrm{m})$ are indicated

$20 \mathrm{mmol} / \mathrm{l}$ glucose alone). Possible reasons why the rise times reported by the SRB imaging are $\sim 1,000$-fold longer than those indicated by the measurements of ATP release are discussed in the ESM text (section 3). In contrast, the HW of the events was constant over a wide range of spot areas (not shown). Notably, $15 \%$ of the events have HWs $>20 \mathrm{~s}$ and required $>30 \mathrm{~s}$ to return to the baseline (Fig. 5e).

In addition to multivesicular exocytosis, we also observed examples of sequential exocytosis that took place in rapid succession $(10 \mathrm{~s})$ within the same part of the beta cell and almost returned to baseline before the next event (Fig. 5f). These events were easily distinguished from the multivesicular events in displaying temporally well-separated stepwise increases in fluorescence (Fig. 5g); 7\% of the events were of this type in islets exposed to $20 \mathrm{mmol} / \mathrm{l}$ glucose alone, which increased to $15 \%$ in the presence of carbachol (Fig. 4h).

Multivesicular and single-vesicle exocytosis imaged with $F M 1-43 F X$ We used the fixable fluorescent styryl dye FM1-43FX [38] to study exocytosis in rat beta cells. This dye cannot cross membranes and only labels membranes in direct contact with the extracellular solution. The cells were exposed to either $20 \mathrm{mmol} / \mathrm{l}$ glucose alone or in combination with $20 \mu \mathrm{mol} / 1$ carbachol (for $30 \mathrm{~s}$ ). The FM1-43FX dye was present only during the last $30 \mathrm{~s}$. Previous observations $[18,39]$ and the present live cell imaging of exocytosis (Fig. 5e) suggest that many of the release events have sufficiently long lifetimes to be captured by this protocol. Figure 6a shows a 3-D reconstruction of the most common type of structures labelled in the presence of $20 \mathrm{mmol} / \mathrm{l}$ glucose alone (ESM Movie 1). Figure 6b summarises the distribution of the length/diameter of these structures labelled by FM1$43 \mathrm{FX}$ in cells exposed to glucose alone; the distribution was nearly Gaussian with a mean of $0.60 \pm 0.05 \mu \mathrm{m}(n=140)$. Fluorescent beads with a diameter of $0.20 \mu \mathrm{m}$ (i.e. similar to the $0.3 \mu \mathrm{m}$ diameter of insulin granules in rat beta cells [40]) had a measured diameter of $0.50 \pm 0.02 \mu \mathrm{m}(n=12)$. The cumulative distribution of these events is shown as the dashed line in Fig. 6c. In cells exposed to carbachol for $30 \mathrm{~s}$ (Fig. 6d), $>15 \%$ of the structures labelled by FM1$43 \mathrm{FX}$ were larger than $\geq 2 \mu \mathrm{m}$. In islets exposed to $20 \mathrm{mmol} /$ 1 glucose alone, the corresponding number was $<5 \%$. A $3-\mathrm{D}$ reconstruction of one of the large events is shown in Fig. 6d (ESM Movie 2) that remain connected to the cell surface. In many cases, these exhibited a serpentine-like morphology (hence these data are quoted as lengths rather than diameters). These events are too big to represent endocytotic vesicles (diameter $=70-80 \mathrm{~nm}[35,36,41])$. The cumulative distribution of the FM1-43FX-labelled structures in cells exposed to glucose in the presence of carbachol is shown as the continuous line in Fig. 6c. The distribution of the events was shifted to the right in the presence of carbachol $(p<0.001)$.

3-D scanning electron microscopy ultrastructural analysis of intact rat islets We examined whether carbachol increases the prevalence of homotypically fused granules 
within the cytosol by serial scanning electron microscopy [23]. Figure 7a shows an $x y$ plane of a beta cell together with 3-D rendered $x z$ and $y z$ planes. Regardless of whether the islets had been treated with carbachol or not, most granules were not connected. However, occasionally prefused multigranular structures were observed (Fig. 7b). On average, carbachol increased the number of homotypically fused granules threefold; in the presence of carbachol, $4 \%$ of the granules were joined to at least another granule (Fig. 7c). The largest number of fused granules observed was six. The example shown was within $\sim 400 \mathrm{~nm}$ of the plasma membrane. In cells exposed to carbachol, the average distance between the multivesicular structure and the plasma membrane averaged $1 \pm 0.2 \mu \mathrm{m}$, with about one-third residing within one granule diameter $(0.3-0.4 \mu \mathrm{m})$ of the plasma membrane. We confirmed the occurrence of multivesicular complexes using transmission electron microscopy, which allows more unequivocal identification of the granule membranes. These experiments provided additional evidence of connected granules (Fig. 7d,e), occasionally adjacent to the plasma membrane.

\section{Discussion}

Our data confirm previous observations [10] that compound multivesicular exocytosis contributes marginally $(<5 \%)$ to glucose-induced insulin secretion. However, multivesicular compound exocytosis of prefused granules becomes quantitatively significant in the presence of carbachol and then accounts for up to $18 \%$ of the events (Figs 4, 5).

We believe that the large $\mathrm{P} 2 \mathrm{X}_{2} \mathrm{R}$-dependent currents and capacitance steps reflect exocytosis of granules that have prefused within the cell before fusing with the plasma membrane rather than individual granules fusing with each other in rapid succession. This conclusion is underpinned by the following observations. First, in the $\mathrm{P} 2 \mathrm{X}_{2} \mathrm{R}$-based assay, the large events described here developed monotonically and there was no sign of any discrete steps that could reflect exocytosis of single granules in rapid succession. Second, the two-photon imaging experiments indicated the occurrence of large exocytotic events that rose without discernible steps of the type seen during sequential exocytosis (compare Fig $5 \mathrm{c}$ and g). Third, confocal imaging of FM1-43FX enabled the identification of large serpentine-like structures in beta cells (Fig. 6d) that had been exposed to carbachol and fixed within the lifetime of the large events determined by the two-photon SRB imaging experiments (Fig. $5 \mathrm{c}, \mathrm{e}$ ).

The dearth of multivesicular complexes reported by the ultrastructural analyses (Fig. 7) compared with the functional measurements indicates that they form shortly before their fusion with the plasma membrane, making them difficult to capture by electron microscopy. In this context, it should be remembered that only a small fraction of the insulin granules undergo exocytosis $(0.1 \% / 20 \mathrm{~min})$, making it difficult to correlate the ultrastructural and functional data.

Is multivesicular exocytosis functionally significant? Consider (for didactic reasons) a beta cell with 100 release sites. If single granules undergo exocytosis at these sites, then a total of 120 granule equivalents will undergo exocytosis in the presence of $20 \mathrm{mmol} / \mathrm{l}$ glucose alone (five multivesicular events comprising five granules and 95 unitary events; i.e. $5 \times 5+95 \times 1$ granule equivalents). However, in the presence of carbachol, multivesicular exocytosis will occur at 18 of these release sites, and a total of 172 granule equivalents will be released (i.e. $82 \times 1+18 \times 5$ ). This stimulation of $43 \%$ is comparable to the $35-49 \%$ stimulation of insulin secretion evoked by carbachol during 1-20 min exposures (Fig. 4i), similar to the stimulation previously reported by others [42]. Thus the stimulation of insulin secretion by carbachol appears largely attributable to an increase in compound exocytosis rather than the frequency. In contrast, agents that increase cAMP (such as glucagon-like peptide 1 [GLP-1]) also increase the frequency of exocytosis $[15,43]$.

What would be the functional significance of compound and sequential exocytosis in the beta cell? We think that the low $\mathrm{Ca}^{2+}$-channel density $\left(0.9 \mu \mathrm{m}^{-2}\right)$ [44], much lower than that reported for chromaffin cells $\left(9-20 \mu \mathrm{m}^{-2}\right)$ [45, 46], provides a clue. Despite their low $\mathrm{Ca}^{2+}$-channel density, pancreatic beta cells are capable of a remarkably high rate of exocytosis, which approaches that in chromaffin cells. Reported maximum rates of capacitance increase $(1.2 \mathrm{pF} / \mathrm{s}$ $[32,44])$ correspond to 300 vesicles being released per second. In compound (as well as sequential) exocytosis, $\mathrm{Ca}^{2+}$ influx via a single $\mathrm{Ca}^{2+}$ channel may suffice to deliver several granules worth of cargo into the islet interstitium using a single fusion site. Such a mechanism may be functionally significant under physiological conditions when insulin demand is very high.

Acknowledgements This work was supported by the Wellcome Trust $(095331 / Z / 11 / Z)$. M. B. Hoppa's DPhil studentship at the University of Oxford was funded by the European Union Integrated Project grant Eurodia.

Contribution statement All authors participated in the conception and design, or analysis and interpretation of data, and drafting the article or revising it critically for important intellectual content. They all read, commented on and approved the final version to be published.

Duality of interest The authors declare that there is no duality of interest associated with this manuscript.

Open Access This article is distributed under the terms of the Creative Commons Attribution Noncommercial License which permits any noncommercial use, distribution, and reproduction in any medium, provided the original author(s) and source are credited. 


\section{References}

1. Rorsman P, Renstrom E (2003) Insulin granule dynamics in pancreatic beta cells. Diabetologia 46:1029-1045

2. Straub SG, Shanmugam G, Sharp GW (2004) Stimulation of insulin release by glucose is associated with an increase in the number of docked granules in the beta-cells of rat pancreatic islets. Diabetes 53:3179-3183

3. Ohara-Imaizumi M, Fujiwara T, Nakamichi Y et al (2007) Imaging analysis reveals mechanistic differences between first- and secondphase insulin exocytosis. J Cell Biol 177:695-705

4. Hanna ST, Pigeau GM, Galvanovskis J, Clark A, Rorsman P, MacDonald PE (2009) Kiss-and-run exocytosis and fusion pores of secretory vesicles in human beta-cells. Pflugers Arch 457:1343-1350

5. Pickett JA, Edwardson JM (2006) Compound exocytosis: mechanisms and functional significance. Traffic 7:109-116

6. Alvarez de Toledo G, Fernandez JM (1990) Compound versus multigranular exocytosis in peritoneal mast cells. J Gen Physiol 95:397-409

7. Hafez I, Stolpe A, Lindau M (2003) Compound exocytosis and cumulative fusion in eosinophils. J Biol Chem 278:44921-44928

8. Cochilla AJ, Angleson JK, Betz WJ (2000) Differential regulation of granule-to-granule and granule-to-plasma membrane fusion during secretion from rat pituitary lactotrophs. J Cell Biol 150:839-848

9. Nemoto T, Kimura R, Ito K et al (2001) Sequential-replenishment mechanism of exocytosis in pancreatic acini. Nat Cell Biol 3:253-258

10. Takahashi N, Hatakeyama H, Okado H et al (2004) Sequential exocytosis of insulin granules is associated with redistribution of SNAP25. J Cell Biol 165:255-262

11. Orci L, Malaisse W (1980) Hypothesis: single and chain release of insulin secretory granules is related to anionic transport at exocytotic sites. Diabetes 29:943-944

12. Lollike K, Lindau M, Calafat J, Borregaard N (2002) Compound exocytosis of granules in human neutrophils. J Leukoc Biol 71:973-980

13. He L, Xue L, Xu J et al (2009) Compound vesicle fusion increases quantal size and potentiates synaptic transmission. Nature 459:93-97

14. Dahl G, Henquin JC (1978) Cold-induced insulin release in vitro: evidence for exocytosis. Cell Tissue Res 194:387-398

15. Kwan EP, Gaisano HY (2005) Glucagon-like peptide 1 regulates sequential and compound exocytosis in pancreatic islet beta-cells. Diabetes 54:2734-2743

16. Takahashi N, Kasai H (2007) Exocytic process analyzed with twophoton excitation imaging in endocrine pancreas. Endocr $\mathrm{J}$ $54: 337-346$

17. Karanauskaite J, Hoppa MB, Braun M, Galvanovskis J, Rorsman P (2009) Quantal ATP release in rat beta-cells by exocytosis of insulin-containing LDCVs. Pflugers Arch 458:389-401

18. Takahashi N, Nemoto T, Kimura R et al (2002) Two-photon excitation imaging of pancreatic islets with various fluorescent probes. Diabetes 51(Suppl 1):S25-S28

19. Obermuller S, Calegari F, King A et al. Defective secretion of islet hormones in chromogranin-B deficient mice. PLoS ONE 5:e8936

20. Kasai H, Hatakeyama H, Kishimoto T, Liu TT, Nemoto T, Takahashi N (2005) A new quantitative (two-photon extracellular polar-tracer imaging-based quantification (TEPIQ)) analysis for diameters of exocytic vesicles and its application to mouse pancreatic islets. J Physiol 568:891-903

21. Braun M, Ramracheya R, Bengtsson M et al (2008) Voltage-gated ion channels in human pancreatic beta-cells: electrophysiological characterization and role in insulin secretion. Diabetes 57:1618-1628

22. Olofsson CS, Gopel SO, Barg S et al (2002) Fast insulin secretion reflects exocytosis of docked granules in mouse pancreatic B cells. Pflugers Arch 444:43-51
23. Denk W, Horstmann H (2004) Serial block-face scanning electron microscopy to reconstruct three-dimensional tissue nanostructure. PLoS Biol 2:e329

24. Patton C, Thompson S, Epel D (2004) Some precautions in using chelators to buffer metals in biological solutions. Cell Calcium $35: 427-431$

25. Obermuller S, Lindqvist A, Karanauskaite J, Galvanovskis J, Rorsman $\mathrm{P}$, Barg S (2005) Selective nucleotide-release from dense-core granules in insulin-secreting cells. J Cell Sci 118:4271-4282

26. MacDonald PE, Braun M, Galvanovskis J, Rorsman P (2006) Release of small transmitters through kiss-and-run fusion pores in rat pancreatic beta cells. Cell Metab 4:283-290

27. MacDonald PE, Rorsman P (2007) The ins and outs of secretion from pancreatic beta-cells: control of single-vesicle exo- and endocytosis. Physiology (Bethesda) 22:113-121

28. Braun M, Wendt A, Karanauskaite J et al (2007) corelease and differential exit via the fusion pore of GABA, serotonin, and ATP from LDCV in rat pancreatic beta cells. J Gen Physiol 129:221-231

29. Galvanovskis J, Braun M, Rorsman P (2011) Exocytosis from pancreatic $\beta$-cells: mathematical modelling of the exit of lowmolecular-weight granule content. Interface Focus 1:143-152

30. Gautam D, Han SJ, Hamdan FF et al (2006) A critical role for beta cell M3 muscarinic acetylcholine receptors in regulating insulin release and blood glucose homeostasis in vivo. Cell Metab 3:449-461

31. Gilon P, Henquin JC (2001) Mechanisms and physiological significance of the cholinergic control of pancreatic beta-cell function. Endocr Rev 22:565-604

32. Ammala C, Eliasson L, Bokvist K, Larsson O, Ashcroft FM, Rorsman P (1993) Exocytosis elicited by action potentials and voltage-clamp calcium currents in individual mouse pancreatic $B$ cells. J Physiol 472:665-688

33. Bokvist K, Eliasson L, Ammala C, Renstrom E, Rorsman P (1995) Co-localization of L-type $\mathrm{Ca}^{2+}$ channels and insulin-containing secretory granules and its significance for the initiation of exocytosis in mouse pancreatic B cells. EMBO J 14:50-57

34. Theler JM, Mollard P, Guerineau N et al (1992) Video imaging of cytosolic $\mathrm{Ca}^{2+}$ in pancreatic beta-cells stimulated by glucose, carbachol, and ATP. J Biol Chem 267:18110-18117

35. Kasai H, Kishimoto T, Nemoto T, Hatakeyama H, Liu TT, Takahashi N (2006) Two-photon excitation imaging of exocytosis and endocytosis and determination of their spatial organization. Adv Drug Deliv Rev 58:850-877

36. MacDonald PE, Eliasson L, Rorsman P (2005) Calcium increases endocytotic vesicle size and accelerates membrane fission in insulin-secreting INS-1 cells. J Cell Sci 118:5911-5920

37. MacDonald PE, Obermuller S, Vikman J, Galvanovskis J, Rorsman P, Eliasson L (2005) Regulated exocytosis and kiss-and-run of synaptic-like microvesicles in INS-1 and primary rat beta-cells. Diabetes 54:736-743

38. Angleson JK, Cochilla AJ, Kilic G, Nussinovitch I, Betz WJ (1999) Regulation of dense core release from neuroendocrine cells revealed by imaging single exocytic events. Nat Neurosci 2:440-446

39. Michael DJ, Ritzel RA, Haataja L, Chow RH (2006) Pancreatic beta-cells secrete insulin in fast- and slow-release forms. Diabetes 55:600-607

40. Braun M, Wendt A, Birnir B et al (2004) Regulated exocytosis of GABA-containing synaptic-like microvesicles in pancreatic beta-cells. J Gen Physiol 123:191-204

41. Hatakeyama H, Takahashi N, Kishimoto T, Nemoto T, Kasai $\mathrm{H}$ (2007) Two cAMP-dependent pathways differentially regulate exocytosis of large dense-core and small vesicles in mouse betacells. J Physiol 582:1087-1098

42. Persaud SJ, Jones PM, Sugden D, Howell SL (1989) The role of protein kinase $\mathrm{C}$ in cholinergic stimulation of insulin secretion from rat islets of Langerhans. Biochem J 264:753-758 
43. Kasai H, Suzuki T, Liu TT, Kishimoto T, Takahashi N (2002) Fast and cAMP-sensitive mode of $\mathrm{Ca}^{2+}$-dependent exocytosis in pancreatic $\beta$-cells. Diabetes 51(Suppl 1):S19-S24

44. Barg S, Ma X, Eliasson L et al (2001) Fast exocytosis with few $\mathrm{Ca}^{2+}$ channels in insulin-secreting mouse pancreatic B cells. Biophys J 81:3308-3323
45. Fenwick EM, Marty A, Neher E (1982) Sodium and calcium channels in bovine chromaffin cells. J Physiol 331:599635

46. Klingauf J, Neher E (1997) Modeling buffered $\mathrm{Ca}^{2+}$ diffusion near the membrane: implications for secretion in neuroendocrine cells. Biophys J 72:674-690 